\title{
Reprogramming efficiency of human embryonic fibroblasts using polycistronic lentiviral expression of reprogramming factors OSKM. Testing of factors that enhance efficiency
}

W.W.M. Pim Pijnappel ( $\nabla$ w.pijnappel@erasmusmc.nl )

Pijnappel/Schöler/Timmers

Erik van der Wal

Holm Zaehres

Hans. R. Schöler

H.T.Marc Timmers

Method Article

Keywords: human reprogramming iPS enhancement

Posted Date: March 19th, 2013

DOI: https://doi.org/10.1038/protex.2013.032

License: (c) (i) This work is licensed under a Creative Commons Attribution 4.0 International License.

Read Full License 


\section{Abstract}

This protocol describes the testing of gene products for enhancement of reprogramming to iPS cells from human embryonic fibroblasts. OSKM factors together with the gene of interest are expressed uisng lentiviruses.

\section{Introduction}

see the associated publication

\section{Reagents}

see the associated publication

\section{Equipment}

see the associated publication

\section{Procedure}

This protocol is associated with the following reference: W.W.M. Pim Pijnappel, Daniel Esch, Marijke P.A. Baltissen, Guangming Wu, Nikolai Mischerikow, Atze J. Bergsma, Erik van der Wal, Dong Wook Han, Hermann vom Bruch, Sören Moritz, Phillip Lijnzaad, A.F. Maarten Altelaar, Katrin Sameith, Holm Zaehres, Albert J. R. Heck, Frank C.P. Holstege, Hans R. Schöler and H.Th. Marc Timmers \(2013). A central role for TFIID in the pluripotent transcription circuitry. Nature, in press. Day $1 \cdot$ Plate 293T cells into $10 \mathrm{~cm}$ dishes $\backslash$ (4 dishes per virus) in a final volume of $9 \mathrm{ml}$ MEF medium per dish. Plate enough cells to obtain $70 \%$ confluence on the next day Day 2 - Transfect the $293 \mathrm{~T}$ cells from day $1 \backslash$ (cells should look $70 \%$ confluent, nicely spread, evenly distributed, without clumps) with Fugene $6 \backslash$ (Promega) as follows: Perform for each virus a separate transfection. Use for 4 dishes $\backslash$ (this will yield $1000 \mu$ l virus after concentration) Tube 1: $328 \mu \mathrm{l}$ Optimem with $72 \mu \mathrm{l}$ Fugene 6 Tube 2: In a total volume of $400 \mu \mathrm{l}$ Optimem: $12 \mu \mathrm{g}$ LV-OSKM or LVgene of interest $8 \mu \mathrm{g}$ psPAX2 $4 \mu \mathrm{g}$ pCMV-VSVG Incubate both tubes for 5 minutes at room temperature. Add tube 2 to tube 1, mix gently by flicking and incubate 15 minutes at room temperature. Add $200 \mu \mathrm{l}$ of the mixture per $10 \mathrm{~cm}$ dish, shake and incubate for 72 hours. Day $4 \cdot$ Plate F134 human embryonic fibroblasts at 100,000 cells per well in a 6 wells plate in MEF medium \(the dish does not need to be gelatinzed). Day 5 - Collect supernatant of dishes with transfected 293T cells and filter through $0.45 \mu \mathrm{m}$ PVDF filters. Spin filtered supernatant by ultra-centrifugation at $20 \mathrm{krpm}$ in an SW32Ti rotor $\backslash$ (Beckman) for $2 \mathrm{hr}$ at $4{ }^{\circ} \mathrm{C}$. Remove supernatant by decanting and dissolve the pellet into $1000 \mu \mathrm{L}$ DMEM low glucose. Use the virus directly to infect cells or store virus for less than 1 week at $4{ }^{\circ} \mathrm{C}$ or for longer periods in aliquots at $-80^{\circ} \mathrm{C}$. Note: When virus production was efficient a white/brown pellet will appear after ultra centrifugation • Infect the plated F134 cells from Day 4 with $50 \mu \mathrm{l}$ of concentrated OSKM virus and $50 \mu \mathrm{l}$ of the concentrated virus expressing the gene of interest. Add to each well $6 \mu \mathrm{g} / \mathrm{ml}$ protamine 
sulfate directly into the medium and mix by swirling. Note: use titration of the amount of OSKM virus to determine the optimal amount of virus that gives a moderate amount of iPS colonies to allow for testing enhancers of reprogramming efficiency. Day $6 \cdot$ Replace medium of the infected F134 cells by washing three times with PBS followed by MEF medium Note: is is also possible to perform this step one day later. Optimal: Check after washing fluorescent signal of tomato red. 48 hours after infection, a light tomato red signal should appear in at least $40 \%$ of the cells. After a couple of days this signal will increase. Day 10 • Plate CF-1 MEF feeder cells with $1,7 \times 10 \mathrm{e} 4$ cells per $\mathrm{cm} 2$ into a gelatinized 6 wells plate. Note: these feeders will be used for 13 days. It is therefore important not to plate the feeders earlier than day 10. Day 11 - Trypsinize infected F134 cells and plate 10,000 cells per well onto the feeders plated at day 11 . Change medium to iPS medium. Day 12 and onwards - Daily refresh the medium with iPS medium. Day 29: count the amount of colonies with iPS-like morphology, and/or process for Tra1-60 colony staining or single cell FACS analysis. Medium composition: MEF medium -445ml DMEM low glucose \(PAA, E15005) -50ml Fetal Bovine Serum \(FBS, Invitrogen \# 16000-044) -5ml Pen/Strep/Glu 100x \(PAA, P11-013) iPS medium -390ml DMEM/F12 \(Invitrogen, \# 21331046) -100ml KO serum replacement $\backslash$ (Invitrogen \# 10828) $-5 \mathrm{~mL}$ Non-essential amino acids $\backslash(P A A, M 11-003)-5 \mathrm{~mL}$ Pen/Strep/Glu 100x \(PAA, P11-013) $-1 \mathrm{ml}$ $\beta$-Mercaptoethanol \(Invitrogen \# 31350010) -1 ml basic fibroblast growth factor $\backslash(\mathrm{bFGF}, 5 \mu \mathrm{g} / \mathrm{ml}$ stock solution in $0.1 \%$ BSA/PBS, Peprotech $100-18 \mathrm{~b}$ ) Sterile filter through $0.2 \mu \mathrm{m}$ filter Store at $4^{\circ} \mathrm{C}$ for up to 2 weeks

\section{Timing}

29 days

\section{Troubleshooting}

see details in the protocol

\section{Anticipated Results}

When usign low lentiviral titers that result in a few colonies after OSKM infection, co-infection with TAF4 virus shoudl lead to a strong increase in the amount of colonies and Tra1-60 positive cells after FACS analysis.

\section{References}

This protocol is associated with the following reference: W.W.M. Pim Pijnappel, Daniel Esch, Marijke P.A. Baltissen, Guangming Wu, Nikolai Mischerikow, Atze J. Bergsma, Erik van der Wal, Dong Wook Han, Hermann vom Bruch, Sören Moritz, Phillip Lijnzaad, A.F. Maarten Altelaar, Katrin Sameith, Holm Zaehres, Albert J. R. Heck, Frank C.P. Holstege, Hans R. Schöler and H.Th. Marc Timmers \(2013). A central role for TFIID in the pluripotent transcription circuitry. Nature, in press. 


\section{Acknowledgements}

We thank Martina Radstaak and Boris Burr for technical assistance 